\title{
The effect of amendments on Lolium perenne roots arbuscular mycorrhizal fungi colonization when cultivated in contaminated soil
}

\author{
A. Szada-Borzyszkowska ${ }^{1}$. J. Krzyżak ${ }^{1}$ - S. Rusinowski ${ }^{1}$ A. Starzewska-Sikorska ${ }^{1}$ I. Ratman-Kłosińska ${ }^{1}$. \\ M. Pogrzeba' ${ }^{1}$ (i)
}

Received: 7 September 2020 / Revised: 24 September 2021 / Accepted: 1 November 2021 / Published online: 21 November 2021

(c) The Author(s) 2021

\begin{abstract}
Arbuscular Mycorrhizal Fungi that colonize the roots of plants growing on lands contaminated by heavy metals may influence the phytostabilization process reducing the translocation of metals to the aboveground parts of the plant. This study aimed to evaluate the effects of soil amendments (lime and lignite) on the concentration of the bioavailable form of heavy metals $\left(\mathrm{CaCl}_{2}\right.$ extraction) in soil and on the colonization of Arbuscular Mycorrhizal Fungi in the roots of Lolium perenne when cultivated in contaminated soil. During the experiment, the bioavailability of $\mathrm{Pb}, \mathrm{Cd}$, and $\mathrm{Zn}$ in soil was significantly reduced after application of the amendments, causing an increase of $L$. perenne shoot dry biomass. It was observed that the higher dose of lime $(0.5 \%)$ resulting in amplified values of relative mycorrhizal intensity. However, independently of the dose, the treatments increased the occurrence of arbuscules in L. perenne roots, with the highest value observed after the application of $0.25 \%$ lime with $5 \%$ lignite. The results for the first time present the effect of lime and lignite application on the L. perenne roots colonization by Arbuscular Mycorrhizal Fungi indicating the increase of occurrence of arbuscules. These findings suggest that in order to explain the different responses of Arbuscular Mycorrhizal Fungi to the applied treatment further investigations are needed to identify the spore morphology. The results of the experiment were implemented to stabilize heavy metals during remediation of a spoil heap in Ruda Śląska, Poland.
\end{abstract}

Keywords Arbuscular mycorrhiza $\cdot$ Heavy metals $\cdot$ Lignite $\cdot$ Lime $\cdot$ Phytostabilization

\section{Introduction}

An incessant growth of industry and other anthropogenic activities have been a cause of some adverse changes in the environment which may indirectly affect human health. A by-product of these activities are heavy metals which lead to soil contamination (Jiang et al. 2018). The most commonly occurring metal(loid)s in contaminated soil are $\mathrm{Pb}, \mathrm{Cd}, \mathrm{Zn}$, As, $\mathrm{Cr}, \mathrm{Cu}, \mathrm{Hg}$, and $\mathrm{Ni}$ (Laghlimi et al. 2015). Those might negatively impact the environment by affecting not only the quality of soil, but the microbial activity of crops and the physiological status of plants as well, leading to a decrease in food quality and safety (Liu et al. 2018; Shahid et al.

Editorial responsibility: Samareh Mirkia.

M. Pogrzeba

m.pogrzeba@ietu.pl

1 Institute for Ecology of Industrial Areas, 6 Kossutha St., 40-844 Katowice, Poland
2015; Yang et al. 2015a, b). The adverse and toxic effects of heavy metals on plants, such as changes in their metabolism and growth limitation, are well known (Emamverdian et al. 2015; Wani et al. 2018). Therefore, it is necessary to deal with contaminants in the soil and seek for solutions that lead to a proper management of degraded areas while reducing environmental hazards associated with them.

Phytoremediation of contaminated soils reduces the risk for human health and supports the environmental restoration of post-industrial and degraded areas. It allows for an effective stabilization and/or elimination of heavy metals at low costs restoring the biological balance in areas excluded from food production (Fiorentino et al. 2018). There are several approaches where plants are used for heavy metal contaminated land restoration including phytoextraction, phytostabilization, phytodegradation, and phytovolatilization (Hanus-Fajerska and Koźmińska 2016). Among them, phytostabilization seems to demonstrate the highest application potential in terms of effectiveness to deal with severely heavy metal contaminated soils. The method consists in 
stabilizing the metals in the rhizosphere and consequently limiting their mobility in soil and translocation to the aboveground biomass (Barbosa and Fernando 2018; Parmar and Singh 2015). Aided phytostabilization consists in using soil amendments along with selected plant species. Such combination can substantially amplify the effect of reducing the concentration of heavy metal bioavailable form in soil and at the same time decrease the metals uptake by plants by increasing the soil $\mathrm{pH}$, organic matter content, etc. (Jin et al. 2016; Liu et al. 2018; Martínez-Martínez et al. 2019; Radziemska 2017, Radziemska et al. 2017). Aided phytostabilization is recommended as a suitable and costeffective technique for heavily metal-polluted soils (Bidar et al. 2016; Gonneau et al. 2017), especially to prevent wind and water erosion on post-mining tailings (Barbosa and Fernando 2018; Luo et al. 2019). This remediation strategy can be used on a large scale, both in rural and industrial areas (Bidar et al. 2016). Aluminosilicates, organic materials, lignite, liming agents, and different phosphorus compounds have been successfully tested in the past as soil amendments (Briceño et al. 2018; Cui et al. 2016; Fresno et al. 2018; Goulding 2016; Shackira and Puthur 2019). The literature data and a number of experiments show that the most desirable features of plant species for phytostabilization are high tolerance to heavy metals, low level of metal accumulation in shoots, and ability to develop extensive root system (Burges et al. 2016; Jutsz and Gnida 2015; Radziemska 2018). Many authors indicated Lolium perenne as a promising species for aided phytostabilization (Kacprzak et al. 2014; Radziemska 2017), including metal contaminated soils from post-industrial areas and mine tailings deposits (España et al. 2019; Hechelski et al. 2019).

Heavy metal uptake may be supported by the activity of soil microorganisms, including Arbucular Mycorrhizal Fungi (AMF) (Gu et al. 2017). AMF are one of the most widespread representatives of microbiota (Della Mónica et al. 2015; Öpik et al. 2013). AMF occur in many habitats, including contaminated sites, where plant growth is limited (Bąba et al. 2016; Gunathilakae et al. 2018; Nowak et al. 2019; Rajtor and Piotrowska-Seget 2016). In recent years, the effect of AMF on phytoremediation process has been considered in many studies (Cabral et al. 2015; Das et al. 2017; Schneider et al. 2016). They showed that the role of $\mathrm{AMF}$ in the phytoremediation process is equally important as the role of plants (Yang et al. 2016). Also, the impact of AMF on heavy metal accumulation in plants has been described in detail (Liu et al. 2015; Zhan et al. 2016).

It is assumed that the presence of AMF may have a significant influence on the efficiency of heavy metal accumulation by host plants which subsequently could improve the phytostabilization process (Rusinowski et al. 2019). AMF may aid plant growth in heavy metal contaminated soils by facilitating the supplementation of essential nutrients in host plants (Cely et al. 2016). It could also improve the tolerance of host plants to heavy metals pollution by, e.g., chelating metals inside the hyphae or its precipitation in polyphosphate granules in the soil (Latef et al. 2016).

In various studies lime was used to increase the $\mathrm{pH}$ of soil to reduce the bioavailability of heavy metals (Heyburn et al. 2017). Also there is data available from the investigations of lignite sorption capability in metals immobilization (Briceño et al. 2018). Using information about the proven properties of both lime and lignite as soil additives (Gucwa-Przepióra et al. 2007), it was proposed to test a combination of them to improve the properties of soil heavily contaminated with $\mathrm{Pb}, \mathrm{Cd}$, and $\mathrm{Zn}$. The purpose of this study was to investigate and assess the application effects of two different combined doses of lignite and lime on soil parameters, including $\mathrm{pH}$ and heavy metals' bioavailability. Moreover, the literature showed the impact of lime on AMF colonization (Heyburn et al. 2017; Seguel et al. 2016), but there is no data available on the effects of a combined application of lignite and lime on Lolium perenne roots AMF colonization process. Therefore study attempted also to assess the impact of soil amendments on the mycorrhizal colonization parameters and $\mathrm{Pb}$, $\mathrm{Cd}$, and $\mathrm{Zn}$ concentration in perennial ryegrass (Lolium perenne cv. STADION). This study was performed in the year 2017, at the facility of the Institute for Ecology of Industrial Areas, Katowice, Poland.

\section{Material and methods}

\section{Experiment design}

The soil for the pot experiment was collected from a spoil heap of a closed-down zinc smelter located in Ruda Śląska (Upper Silesia, Poland). The soil was highly contaminated with heavy metals, particularly $\mathrm{Pb}, \mathrm{Cd}$, and $\mathrm{Zn}$. Soil samples were collected in 2017 from spots where the highest concentration of the bioavailable forms of heavy metals was found, from a depth of $0-25 \mathrm{~cm}$. The selection of spots was based on data from a previous chemical analysis of soil from the site and the GIS data. The collected soil was air-dried, passed through a $4 \mathrm{~mm}$ sieve and transferred into plastic pots. Five pots $\left(0.0015 \mathrm{~m}^{3}\right.$ volume each) for each treatment were prepared and labeled as follows:

- Non-amended soil (C),

- Soil amended with 5\% (w/w) lignite and $0.5 \%(\mathrm{w} / \mathrm{w})$ lime (LL_I),

- Soil amended with 5\% (w/w) lignite and $0.25 \%(\mathrm{w} / \mathrm{w})$ lime (LL_II).

To control the stabilization process, soil samples were collected three times: at the beginning of the experiment 
and subsequently after two and six weeks. Soil samples were air-dried and sieved through $<2 \mathrm{~mm}$ sieve to remove large particles for $\mathrm{pH}$ and electric conductivity determination and then through $<0.25 \mathrm{~mm}$. The concentrations of the bioavailable forms $\left(\mathrm{CaCl}_{2}\right.$ extractable fraction) and pseudo-total concentrations of heavy metals $(\mathrm{Pb}, \mathrm{Cd}$, and $\mathrm{Zn}$ ) were measured. Subsequently, Lolium perenne cv. STADION was sown and cultivated in the growing chamber under controlled conditions: temperature $24^{\circ} \mathrm{C}$, $300 \mu \mathrm{mol}$ (photons) $\mathrm{m}^{-2} \mathrm{~s}^{-1}$, and humidity $50 \%$. The aboveground parts of the plants were harvested after six and thirteen weeks after the sowing. Additionally, at the end of the experiment, root samples were collected. The root samples were divided into two parts, one for each experimental treatment and one for replication, to estimate the mycorrhizal colonization parameters. The remaining roots and the aboveground parts of the plants, were washed with tap water to remove soil particles, and then again with deionized water. Subsequently, plant material was dried for 3 days at $70{ }^{\circ} \mathrm{C}$ and, after constant weight was achieved, the samples were milled to a homogeneous powder $(<1 \mathrm{~mm})$ for further analysis $(\mathrm{Pb}, \mathrm{Cd}$, and $\mathrm{Zn}$ concentration). The possible limitations of the experiment are related to the scale as it was conducted in pots, where limited amount of soil is provided and might only in some extend reflect the process in open-environment. Another limitations is related to conduct experiment in controlled conditions, which do not reflect the fluctuations of environment variables during field implementation. However, to investigate organisms behavior limiting effect of variables is required to draw initial conclusions before fullscale implementations.

\section{Analysis of soil}

The physicochemical properties of soil, such as $\mathrm{pH}$ and electrical conductivity (EC), were measured according to standardized methods. Soil $\mathrm{pH}$ was analyzed in $\mathrm{H}_{2} \mathrm{O}$ and $1 \mathrm{M} \mathrm{KCl}$ (ratio 1:2.5 m/v) with a combination of glass and calomel electrode (OSH 10-10, METRON, Poland) and a pH-meter (CPC-551, Elmetron, Poland). The EC was measured using an ESP 2 ZM electrode (EUROSENSOR, Poland) according to the Polish norm PN-ISO 11265:1997, using the same device as for $\mathrm{pH}$. To analyze the concentrations of the bioavailable forms of metals $(\mathrm{Cd}, \mathrm{Pb}$, and $\mathrm{Zn}$ ) soil extraction with $0.01 \mathrm{M} \mathrm{CaCl}_{2}$ was used according to the method described by Pogrzeba et al. (2017). Afterward, the concentrations of the bioavailable forms of $\mathrm{Cd}$, $\mathrm{Pb}$, and $\mathrm{Zn}$ were determined in filtrates by flame atomic absorption spectrometry (iCE 3500 FAAS, Thermo Scientific). Pseudo-total metal concentrations were analyzed by extraction using aqua regia digestion according to ISO
11466:1995 and measured using flame atomic absorption spectrometry (iCE 3500 FAAS, Thermo Scientific).

\section{Heavy metals concentration in plants}

Concentrations of $\mathrm{Pb}, \mathrm{Cd}$, and $\mathrm{Zn}$ were determined using flame atomic absorption spectroscopy (iCE 3500 FAAS, Thermo Scientific) after hot plate digestion of dried milled biomass samples at $80{ }^{\circ} \mathrm{C}$ in nitric and perchloric acid (4:1 v/v) (Schierup and Larsen, 1981).

\section{Translocation and bioconcentration factors}

The translocation factor (TF), which was used to estimate the translocation of metals from roots to shoots, was calculated according to Malik et al. (2010):

$\mathrm{TF}=\frac{\text { metal concentration in aboveground parts of the plant }\left(\mathrm{mg} \mathrm{kg}^{-1}\right)}{\text { metal concentration in belowground parts of the plant }\left(\mathrm{mg} \mathrm{kg}^{-1}\right)}$

Bioconcentration factor (BCF) was estimated according to Zhuang et al. (2007) formula:

$\mathrm{BCF}=\frac{\text { metal concentration in the plant tissue }\left(\mathrm{mg} \mathrm{kg}^{-1}\right)}{\text { metal concentration in the soil }\left(\mathrm{mg} \mathrm{kg}^{-1}\right)}$.

\section{Arbuscular mycorrhiza colonization}

To estimate the AMF colonization parameters, the roots were prepared according to Philips and Hayman (1970) method. The roots were cut into $2 \mathrm{~cm}$ segments, and then rinsed in $7 \% \mathrm{KOH}$ for $24 \mathrm{~h}$. Afterward, the roots were acidified in 5\% lactic acid for $24 \mathrm{~h}$ and stained with $0.05 \%$ aniline blue in lactic acid for $24 \mathrm{~h}$. The percentage of mycorrhizal root colonization was assessed with a microscope Zeiss Axio Imager D2 (Zen 2 software, Zeiss, Germany) according to Trouvelot et al. (1986) method. Then the colonization parameters were calculated using MYCOCALC software (http://www.dijon.inra.fr/mychintec/Mycocal-prg/downl oad.html). The parameters measured were: the mycorrhizal frequency $(\mathrm{F} \%)$, relative mycorrhizal intensity $(\mathrm{M} \%)$, and relative abundance of arbuscules (A\%).

\section{Statistical analysis}

All analyses were performed using Statistica 13.1 (Dell, US). Initially, the dataset was checked for normal distribution. The results were then used for the selection of tests to define significant difference of data between three or more independent groups (F-test for normal distribution, Kruskal-Wallis test for distribution other than normal). To remain concise and clear in data presentation, as long as the 
test selection algorithm lead to post hoc tests (ANOVA), the results of post hoc tests were presented on Figures and Tables. Fisher LSD post hoc test was used for denote significant differences between groups (experimental treatments, $P \leq 0.05)$. All presented means were expressed with \pm SE.

\section{Results and discussion}

\section{Soil characteristics}

The physical and chemical parameters of the soil are presented in Table 1. The soil $\mathrm{pH}$ in the control variant during the experiment was slightly acidic, while the application of lime and lignite caused an increase of $\mathrm{pH}$ to neutral. Also Lahori et al. (2017) confirmed the effect of lime on $\mathrm{pH}$ increase, but they used hydrated lime $\left(\mathrm{Ca}(\mathrm{OH})_{2}\right)$ alone or combined with other additives. They also noticed a drop in soil $\mathrm{pH}$ without additives, which could be related to the influence of the rhizosphere on increasing soil $\mathrm{pH}$ acidity. Similar results were obtained by Singh and Kalamdhad (2016). For all investigated treatments, the electrical conductivity (EC) was low (121-176 $\mu \mathrm{S} \mathrm{cm}^{-1}$ ). During the experiment, a reduction of the EC value was observed for control, while an increase and no changes of the value were observed for LL_I and LL_II treatments, respectively. The first visible changes in the $\mathrm{EC}$ value between the control and LL_I treatments occurred after 6 weeks from the start of the experiment. Pseudo-total $\mathrm{Pb}$ concentration was 22 $693 \mathrm{mg} \mathrm{kg}^{-1}$, Cd $100 \mathrm{mg} \mathrm{kg}^{-1}$ and $\mathrm{Zn}$ was $41461 \mathrm{mg} \mathrm{kg}^{-1}$ in initial soil samples. The permissible heavy metal concentration in the soil used for the experiment was surpassing limits for industrial areas defined in Polish regulations (Official Journal of Laws of the Republic of Poland of 2016, item 1395). The total lead concentration exceeded the limits set in the regulation 38 -fold, whereas the total cadmium and zinc concentration did so sevenfold and 41-fold, respectively.

The values of the bioavailable forms of the investigated heavy metals significantly decreased after application of the amendments when compared to the control, irrespective of the dose. A decrease by $70 \%$ and $90 \%$ of bioavailable $\mathrm{Pb}$ was observed in LL_I treatment for sampling date $\mathrm{T} 1$ and T2, respectively, and by $80 \%$ in LL_II treatment. Similar results were found for Cd bioavailable forms: Both treatments decreased the $\mathrm{Cd}$ bioavailable concentration by about $87 \%$ when compared to the control. For $\mathrm{Zn}$ bioavailable form, the treatments resulted in a decrease by about $90 \%$ in comparison to the values in the control. It demonstrates that soil $\mathrm{pH}$ might play a significant role as a factor inhibiting the bioavailability of these metals in the treated soil. Changes of soil $\mathrm{pH}$ may influence the availability and mobility of heavy metals via hydrolysis, complexation by organic or inorganic ligands, redox reactions (Singh and Kalamdhad 2013). Moreover, obtained results are in agreement with Cao et al. (2018), who showed a decrease in heavy metals bioavailability after lignite and lime application to a heavy metal contaminated soil. Lahori et al. (2017) showed decrease of DTPA-extractable fraction of $\mathrm{Pb}, \mathrm{Cd}, \mathrm{Cu}$, and $\mathrm{Zn}$, after lime application. Also, Amoah-Antwi et al. (2020) showed reduction in bioavailability of heavy metals such as $\mathrm{Pb}, \mathrm{Cd}$, and $\mathrm{Zn}$, after application to soil $5 \%$ and $10 \%$ brown coal waste.

\section{Heavy metal concentration and plant biomass production}

The concentration of heavy metals in L. perenne roots and shoots and biomass production is presented in Table 2. The heavy metal concentration differed firmly between plant

Table 1 Physicochemical parameters and heavy metals concentration of soil

\begin{tabular}{|c|c|c|c|c|c|c|c|c|c|}
\hline & \multicolumn{9}{|l|}{ Value } \\
\hline & \multicolumn{3}{|l|}{ Control } & \multicolumn{3}{|l|}{ LL_I } & \multicolumn{3}{|l|}{ LL_II } \\
\hline & $\mathrm{T} 0$ & $\mathrm{~T} 1$ & $\mathrm{~T} 2$ & T0 & $\mathrm{T} 1$ & $\mathrm{~T} 2$ & T0 & $\mathrm{T} 1$ & $\mathrm{~T} 2$ \\
\hline \multicolumn{10}{|c|}{ Physicochemical soil parameters } \\
\hline $\mathrm{pH}\left(\mathrm{H}_{2} \mathrm{O}\right)$ & $6.56 \pm 0.03 b$ & $6.42 \pm 0.03 b^{*}$ & $6.53 \pm 0.01 \mathrm{c}$ & $6.86 \pm 0.01 \mathrm{a}^{*}$ & $7.05 \pm 0.02 \mathrm{a}$ & $7.21 \pm 0.01 \mathrm{a}$ & $6.86 \pm 0.02 \mathrm{a}^{*}$ & $7.05 \pm 0.02 \mathrm{a}$ & $7.14 \pm 0.01 b$ \\
\hline $\mathrm{pH}(\mathrm{KCl})$ & $6.02 \pm 0.03 b$ & $5.97 \pm 0.03 c^{*}$ & $6.02 \pm 0.01 b$ & $6.41 \pm 0.01 \mathrm{a}^{*}$ & $6.47 \pm 0.02 b^{*}$ & $6.61 \pm 0.01 \mathrm{a}$ & $6.38 \pm 0.02 \mathrm{a}^{*}$ & $6.55 \pm 0.02 \mathrm{a}$ & $6.68 \pm 0.01 \mathrm{a}$ \\
\hline $\mathrm{EC}\left(\mu \mathrm{S} \mathrm{cm}^{-1}\right)$ & $176 \pm 0.01 \mathrm{a}$ & $155 \pm 0.01 \mathrm{a}^{*}$ & $145 \pm 0.02 b^{*}$ & $107 \pm 0.03 \mathrm{~b}^{*}$ & $155 \pm 0.01 \mathrm{a}$ & $177 \pm 0.04 \mathrm{a}$ & $157 \pm 0.06 \mathrm{a}$ & $121 \pm 0.03 \mathrm{a}^{*}$ & $159 \pm 0.0 \mathrm{ab}$ \\
\hline \multicolumn{10}{|c|}{ Bioavailable heavy metals concentration ( $\mathrm{CaCl}_{2}$ extraction) } \\
\hline $\mathrm{Pb}\left(\mathrm{mg} \mathrm{kg}^{-1}\right)$ & $1.70 \pm 0.05 \mathrm{a}$ & $1.75 \pm 0.09 \mathrm{a}$ & $1.58 \pm 0.06 \mathrm{a}$ & $0.46 \pm 0.0 \mathrm{~b}$ & $0.43 \pm 0.1 \mathrm{~b}$ & $0.35 \pm 0.05 b$ & $0.27 \pm 0 \mathrm{c}$ & $0.29 \pm 0.0 \mathrm{~b}$ & $0.35 \pm 0.03 b$ \\
\hline $\mathrm{Cd}\left(\mathrm{mg} \mathrm{kg}^{-1}\right)$ & $5.40 \pm 0.22 \mathrm{a}$ & $5.44 \pm 0.07 \mathrm{a}$ & $5.05 \pm 0.17 \mathrm{a}$ & $0.86 \pm 0.03 b$ & $0.74 \pm 0.08 \mathrm{~b}$ & $0.57 \pm 0.03 \mathrm{~b}^{*}$ & $0.58 \pm 0.03 b^{*}$ & $0.50 \pm 0.05 \mathrm{c}^{*}$ & $0.81 \pm 0.01 \mathrm{~b}$ \\
\hline $\mathrm{Zn}\left(\mathrm{mg} \mathrm{kg}^{-1}\right)$ & $122 \pm 1.40 \mathrm{a}$ & $127 \pm 1.90 \mathrm{a}$ & $108 \pm 0.73 \mathrm{a}^{*}$ & $9.54 \pm 0.68 b$ & $7.69 \pm 0.89 b^{*}$ & $6.37 \pm 0.24 \mathrm{c}^{*}$ & $6.63 \pm 0.2 b^{*}$ & $5.85 \pm 0.55 b^{*}$ & $10 \pm 0.26 \mathrm{~b}$ \\
\hline
\end{tabular}

Values are mean, $\pm \mathrm{SE}, n=5$. Asterisks $(*)$ denote significant differences between parameters while considering the time of collection within one variant, and lower case letters $(\mathrm{a}, \mathrm{b}, \mathrm{c})$ denote significant differences between different variants separately for the time of collection, according to Fisher LSD test $(P \leq 0.05)$. T0 - initial soil sampling; T1—second soil sampling (two weeks after amendment application); T2 - third soil sampling (six weeks after amendment application). C - control, LL_I_-5\% lignite and 0.5\% lime, LL_II_-5\% lignite and $0.25 \%$ lime 
Table 2 Concentration of heavy metals in shoots and roots of Lolium perenne and shoot dry weight

\begin{tabular}{lrrr}
\hline & \multicolumn{3}{c}{ Variant } \\
\cline { 2 - 4 } & $\mathrm{C}$ & LL_I & \multicolumn{1}{c}{ LL_II } \\
\hline HM concentration in shoots & & \\
$\mathrm{Pb}\left(\mathrm{mg} \mathrm{kg}^{-1}\right)$ & $21.659 \pm 2.6 \mathrm{a}$ & $19.720 \pm 2.6 \mathrm{a}$ & $19.483 \pm 3.0 \mathrm{a}$ \\
$\mathrm{Cd}\left(\mathrm{mg} \mathrm{kg}^{-1}\right)$ & $9.631 \pm 0.6 \mathrm{a}$ & $330.51 \pm 17 \mathrm{~b}$ & $5.608 \pm 0.4 \mathrm{~b}$ \\
$\mathrm{Zn}\left(\mathrm{mg} \mathrm{kg}^{-1}\right)$ & $436.8 \pm 17.5 \mathrm{a}$ & & $321.995 \pm 11.1 \mathrm{~b}$ \\
HM concentration in roots & & $1680.79 \pm 31.5 \mathrm{c}$ & \\
$\mathrm{Pb}\left(\mathrm{mg} \mathrm{kg}^{-1}\right)$ & $2760.7 \pm 50.1 \mathrm{a}$ & $221.397 \pm 11.8 \mathrm{a}$ & $260.752 \pm 30.1 \mathrm{a}$ \\
$\mathrm{Cd}\left(\mathrm{mg} \mathrm{kg}^{-1}\right)$ & $258.67 \pm 32.3 \mathrm{a}$ & $11,629.236 \pm 671.4 \mathrm{~b}$ & $7667.332 \pm 716.1 \mathrm{c}$ \\
$\mathrm{Zn}\left(\mathrm{mg} \mathrm{kg}^{-1}\right)$ & $13,945.2 \pm 465.0 \mathrm{a}$ & & \\
Shoot dry weight & & $2.113 \pm 0.33 \mathrm{a}$ & $2.430 \pm 0.32 \mathrm{a}$ \\
\hline
\end{tabular}

Values are mean, \pm SE, $n=10$. Lower case letters $(\mathrm{a}, \mathrm{b}, \mathrm{c})$ denote significant differences between different variants, separately for the parameters, according to the Fisher LSD test $(P \leq 0.05)$. C—control, LL_I $-5 \%$ lignite and $0.5 \%$ lime, LL_II-5\% lignite and $0.25 \%$ lime shoots and roots. Heavy metals were predominantly accumulated in the roots.

Along with the decrease in the content of the bioavailable fraction of heavy metals, the translocation of metals to shoots of L. perenne also decreased (Xiao et al. 2019). In the treatments with lime and lignite, the $\mathrm{Pb}$ concentration in shoots was lower by about $9 \%$ (LL_I) and 10\% (LL_II) than the concentration in the control, however values were not significantly differ. The used amendments significantly decreased the Cd concentration in shoots-by about $37 \%$ (LL_I) and $42 \%$ (LL_II). Also compared to the control, the $\mathrm{Zn}$ concentration in the amended treatments was lower by about 24\% (LL_I) and 26\% (LL_II). Lower Cd-uptake by L. perenne after lignite application was also confirmed by Simmler et al. (2013).

Concerning the roots, lime and lignite addition resulted in a similar effect causing a significant decrease of $\mathrm{Pb}$ and $\mathrm{Zn}$ concentrations in the amended treatments compared with the control, except for $\mathrm{Cd}$. The concentration of $\mathrm{Pb}$ in the roots of the control treatment was higher by $40 \%$ and $30 \%$ than in the case of LL_I and LL_II, respectively, and for $\mathrm{Zn}$ by $18 \%$ and $48 \%$. It might be attributed to the absorption of the metal on the root surface which, consequently, limits the transport to the aboveground parts of the plant (Pogrzeba et al. 2019). Radziemska et al. (2018) reported a reduction of $\mathrm{Cu}$ concentration in the aboveground parts of $L$. perenne after the application of lime and diatomite to the soil. Moreover, a lower heavy metal concentration in the roots of the amended treatments may be associated with the mycorrhizal root colonization, especially that the ability of AMF to stabilize heavy metals by hyphae on the surface of the roots was previously reported (Wu et al. 2016).

Zhang et al. (2018) showed that contamination of soil with $\mathrm{Cd}$ may adversely affect the growth and biomass of L. perenne. This is confirmed by our research, where after the application of amendments, along with decrease fraction of bioavailability of heavy metals, increase in dry mass of shoots was observed. Compared to the control, the dry weight of the shoots was higher by $12 \%$ (LL_I) and $24 \%$ (LL_II). Also, this phenomena were observed in previous studies after application of lime (Hartley and Lepp 2008) and $\mathrm{FeSO}_{4}$ with lime to the soil (Moreno-Jimenez et al. 2017).

\section{Translocation and bioaccumulation of heavy metals}

A characteristic feature of L. perenne is an ineffective heavy metals translocation process from roots to shoots. The potential of ryegrass as a candidate species for phytostabilization was expressed in the low translocation factor (TF), which is typically used to estimate the phytoremediation potential of plants. According to Lee et al. (2014), the plant species suitable for phytostabilization should be characterized by $\mathrm{TF}<1$. This findings are confirmed with numerous other studies, which have reported L. perenne to be a suitable species for the phytostabilization process (Norini et al. 2019; Radziemska et al. 2018). Zn was translocated more effectively than the other two metals in both of the amended treatments (Table 3). Research of Gu et al. (2017) shows that AM fungi can effectively support the plant in the uptake and translocation of $\mathrm{Zn}$ into shoots, which was confirmed by the results of BCF and TF in case of $L$. perenne inoculated with mycorrhiza. The addition of lime and lignite significantly increased $\mathrm{Pb}$ and decreased $\mathrm{Cd}$ translocation. The addition of $0.25 \%$ lime enhanced $\mathrm{Zn}$ translocation, while no significant differences between LL_I treatment and control were observed. Bioaccumulation of $\mathrm{Cd}$ and $\mathrm{Zn}$ was lower after amendments application. L. perenne root colonizing by mycorrhiza can additionally inhibit metal translocation from roots to shoots (Gu et al. 2017; Zhang et al. 2018), 
Table 3 The efficiency of $L$. perenne in translocating metals from roots to shoots

\begin{tabular}{llll}
\hline & Control & LL_I & LL_II \\
\hline $\mathrm{TF}_{\mathrm{Pb}}$ & $0.00 \pm 0.0 \mathrm{~b}$ & $0.01 \pm 0.0 \mathrm{a}$ & $0.01 \pm 0.0 \mathrm{a}$ \\
$\mathrm{TF}_{\mathrm{Cd}}$ & $0.03 \pm 0.0 \mathrm{a}$ & $0.02 \pm 0.0 \mathrm{~b}$ & $0.02 \pm 0.0 \mathrm{~b}$ \\
$\mathrm{TF}_{\mathrm{Zn}}$ & $0.03 \pm 0.0 \mathrm{~b}$ & $0.03 \pm 0.0 \mathrm{~b}$ & $0.04 \pm 0.01 \mathrm{a}$ \\
$\mathrm{BCF}_{\mathrm{Pb}}$ & $0.00 \pm 0.00 \mathrm{a}$ & $0.00 \pm 0.00 \mathrm{a}$ & $0.00 \pm 0.0 \mathrm{a}$ \\
$\mathrm{BCF}_{\mathrm{Cd}}$ & $0.10 \pm 0.01 \mathrm{a}$ & $0.06 \pm 0.01 \mathrm{~b}$ & $0.06 \pm 0.0 \mathrm{~b}$ \\
$\mathrm{BCF}_{\mathrm{Zn}}$ & $0.01 \pm 0.00 \mathrm{a}$ & $0.01 \pm 0.00 \mathrm{~b}$ & $0.01 \pm 0.0 \mathrm{~b}$ \\
\hline
\end{tabular}

Values are means $\pm \operatorname{SE}(n=5)$. Lower case letters $(\mathrm{a}, \mathrm{b}, \mathrm{c})$ denote a significant difference between variants in a row according to the Fisher LSD test at $P \leq 0.05$. TF Translocation factor, BCF Bioaccumulation factor. $\mathrm{C}-$ control, $\mathrm{LL}_{-} \mathrm{I}-5 \%$ lignite and $0.5 \%$ lime, $\mathrm{LL}_{-}$ II- $5 \%$ lignite and $0.25 \%$ lime

because heavy metals can be retained in mycorrhizal structures for example by bind to hyphae (Malcová et al. 2003; Joner et al. 2000). Moreover, Begum et al. (2019) showed that a symbiosis between AMF and host plants could enable selective transport mechanisms of both essential elements and heavy metals. For example, the presence of mycorrhiza may increase $\mathrm{Pb}$ uptake in polluted areas (Yang et al. 2016). A limited translocation of $\mathrm{Pb}$ and $\mathrm{Cd}$ to the aboveground parts of the plant might occur either due to the complexation of these metals in the root cells or lack of specific transport channels (Xin et al. 2018), especially for metals which are not essential for physiological processes, like cadmium and lead. $\mathrm{Cd}^{2+}$ and $\mathrm{Pb}^{2+}$ are ions which may become extremely toxic for the plant (Chen et al. 2017): They disturb redox homeostasis (Khanna et al. 2020) and lead to the inhibition of plant growth and yield reduction (Chen et al. 2017). Specific transport channels not only play a crucial role in metals transport, but also prevent the accumulation of heavy metals in toxic levels. One of the prevention mechanisms is a limited translocation of heavy metals to shoots (Hossain et al. 2012).

\section{Mycorrhizal colonization studies}

Phytoremediation processes involving plants capable of symbiosis with indigenous AM fungus may bring promising effects (Miransari 2010). However, AMF colonization in contaminated soils depend on availability of nutrients and climate (Smith and Read 2010). Due to the potential of $L$. perenne in phytostabilization, determination of AMFs' root colonization in soil contaminated with heavy metals and the effect of used soil additives on the AM fungi was investigated. Microscopic observations showed that root samples of L. perenne, both treated and control, were colonized by AMF. In all examined roots the structures characteristic for AM fungi such as arbuscules (Arb), intracellular hyphae (Ih), and vesicles (v) were found (Figs. 1, 2, 3). To describe the characteristics of the mycorrhizal structure development the following parameters were used: mycorrhizal frequency (F\%), relative mycorrhizal intensity (M\%), and relative abundance of arbuscules (A\%). Also, dark septate endophytes (DSE) and microsclerotia were found in the observed root fragments irrespectively of the treatments, which was confirmed by Zhang et al. (2013) in plant roots on Pb- and
Fig. 1 Mycorrhizal structures in L. perenne roots in the control variant. a v (vesicle); b Ih (intracellular hyphae), Eh (extracellular hyphae); c Arb (arbuscules)
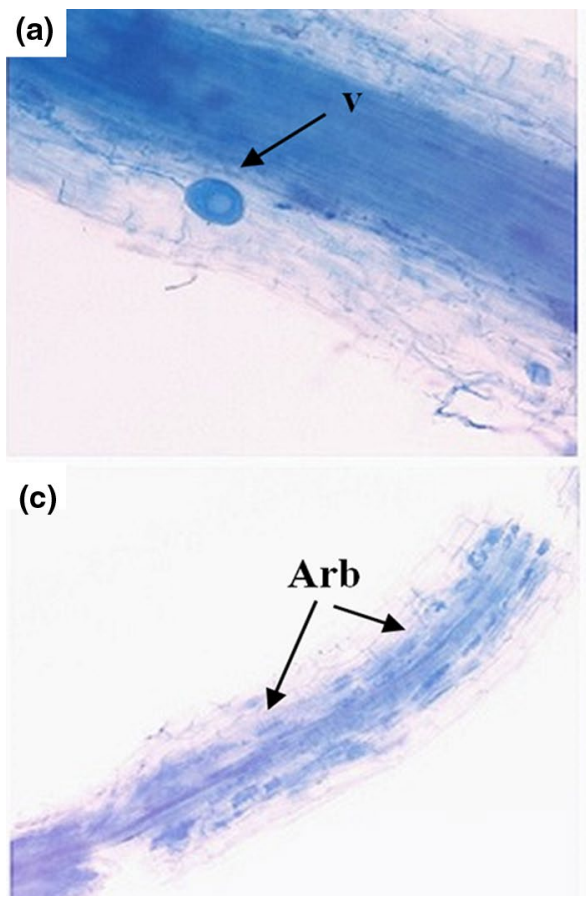

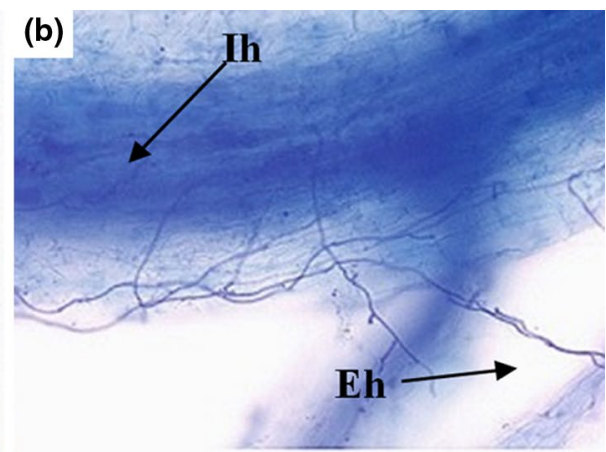


Fig. 2 Mycorrhizal structures in L. perenne roots in the soil amended with $5 \%$ of lignite and $0.5 \%$ of lime. a Arb (arbuscules); b v (vesicle); c Ih (intracellular hyphae), Eh (extracellular hyphae)

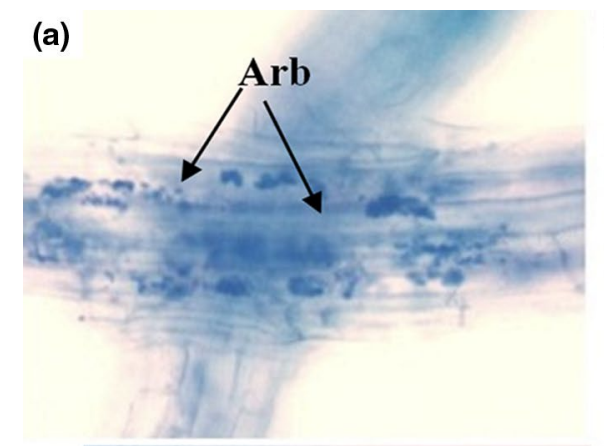

(b)
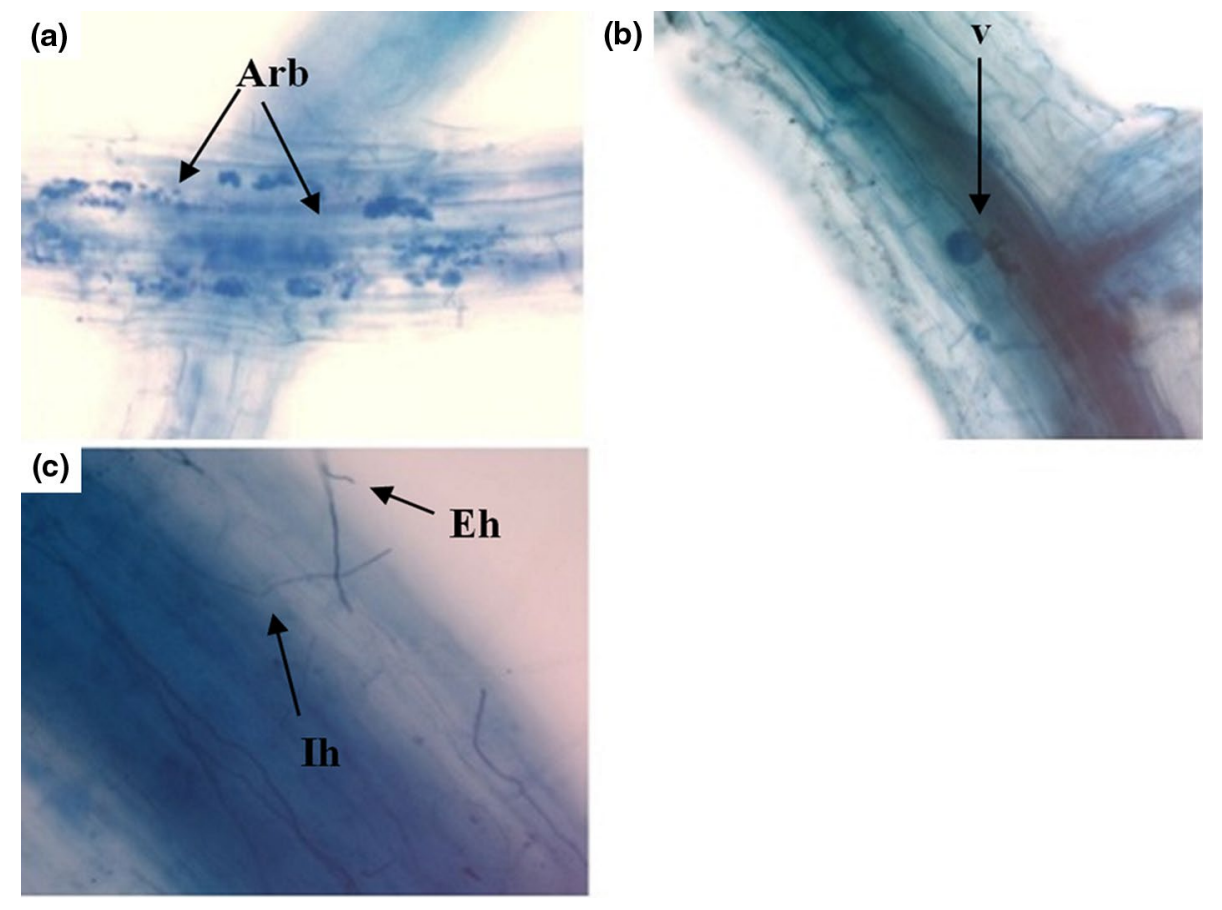

Fig. 3 Mycorrhizal structures in L. perenne roots in the soil amended with $5 \%$ of lignite and $0.25 \%$ of lime. a v (vesicle); $\mathbf{b}$ Ih (intracellular hyphae); c Arb (arbuscules);
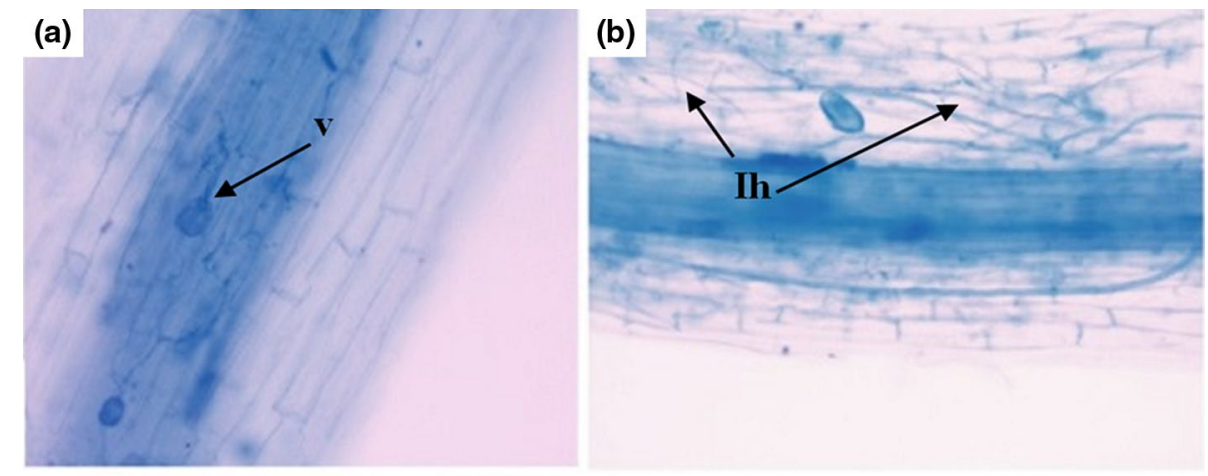

(c)

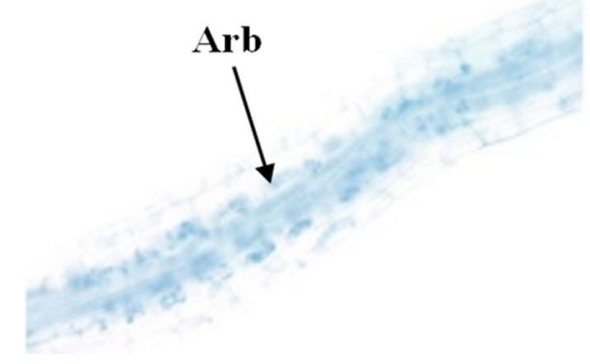

Zn-slag heaps. Despite reports showing the negative impact of high levels of heavy metals in soil on AMF root colonization (Chang et al. 2018; Rusinowski et al. 2019), high value of frequency of mycorrhizal colonization approx. $95 \%$ was observed for $L$. perenne roots in the presented study (Fig. 4). This phenomena is consistent with previous reports, showed a strong symbiotic relationship between AMF and
L. perenne, confirmed by studies conducted on various soil types in 40 geographically dispersed sites (Hazard et al. 2013), grasslands, arable lands (Hazard et al. 2014), and contaminated soil (Zhang et al. 2018). What differentiate this study from the similar research, is the use of autochtonous AMF communities originated from collected soil, whereas most of the research are focused on investigation 


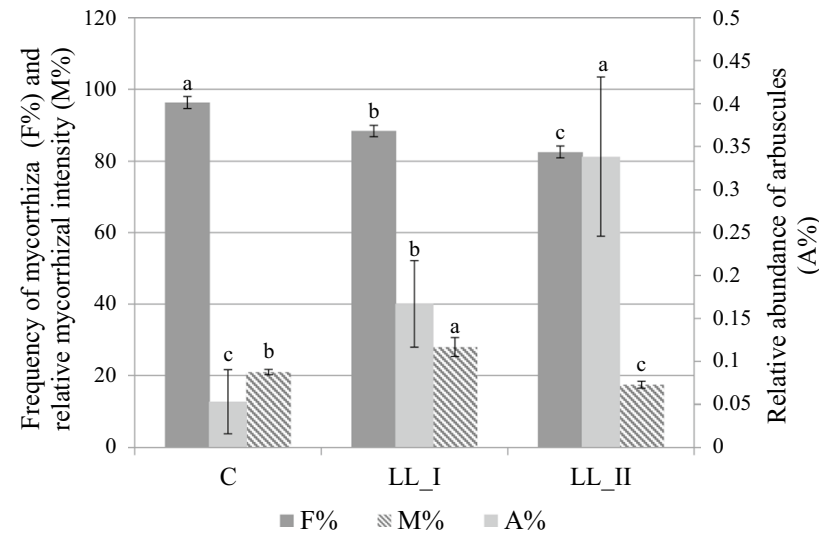

Fig. 4 L. perenne root Arbuscular Mycorrhiza Colonization. Lower case letters $(\mathbf{a}, \mathbf{b}, \mathbf{c})$ denote significant differences between different variants separately for each parameter. F\%-mycorrhizal frequency; M\%-relative mycorrhizal intensity; A\% - the relative arbuscular richness

of AMF provided via inoculation (Berthelot et al. 2018; Orłowska et al. 2010).

The effectiveness of mycorrhizal fungi depends on the soil pH (Carballar-Hernández et al. 2017; Li et al. 2017; Hazard et al. 2013). However, previously conducted studies do not give a clear answer how soil $\mathrm{pH}$ changes affect the colonization of AMF. According to Lin et al. (2017), the development of indigenous mycorrhizal fungi can be inhibited at the highest $\mathrm{pH}$ levels, whereas Parihar et al. (2019) showed that high $\mathrm{pH}$ favors high values of mycorrhizal frequency. The effect of the application of lime and lignite on the mycorrhizal colonization in the L. perenne root system is shown in Fig. 4. There were significant differences in mycorrhizal colonization parameters ( $\mathrm{F} \%, \mathrm{M} \%$, and A\%) among experimental variants. Lower values of mycorrhizal frequency $(\mathrm{F} \%)$ were noted in samples with higher $\mathrm{pH}$ value and lower concentration of bioavailable forms of heavy metals, when compared to the control treatment. The frequency of mycorrhiza in the amended treatments was considerably lower than in the control: by $8 \%$ (LL_I) and $14 \%$ (LL_II), respectively. This phenomenon may be related to the increase in organic matter added in form of lignite, as confirmed by the results of studies by Yang et al. (2015a, b), where F\% was negatively correlated with the content of organic matter in the soil. Amendments slightly changed mycorrhizal intensity dependent on dose of lime: higher lime dose increased of M\% by about 30\%, whereas lower lime dose decreased $\mathrm{M} \%$ by $17 \%$, compared to the control. Interestingly, both of used amendments amplified significantly the development of arbuscules, and at the same time it led to a reduction of other mycorrhizal structures such as hyphae and vesicles. Previous studies presented various impacts of soil treatments such as liming (Gomes et al. 2015; Heyburn et al. 2017; Nava et al. 2016) or application of lignite in combination with calcium phosphate (GucwaPrzepióra et al. 2007) on mycorrhizal colonization. The studies of Gucwa-Przepióra et al. (2007), showed an increase in the development of AMF in Deschampsia cespitosa roots caused by the application of mixed calcium phosphate and lignite, but indicated that $\mathrm{EC}$ and $\mathrm{pH}$ did not affect native AM colonization level. Differences between presented study and Gucwa-Przepióra et al. (2007) are associated with the use of phosphorus compounds which modify soil properties in terms of primary macronutrients availability (particularly P), what was not true for this study. Nava et al. (2016) showed a positive influence of liming on mycorrhizal colonization effectiveness in Acca sellowiana. The discrepancy in the results may be due to the fact that, the effectiveness AMF colonization may depend on the mycorrhizal species and their tolerance to practices in crop management (Junior et al. 2019), as well as on host plants and environmental conditions (Oehl et al. 2003). However, there is no information how changes in soil properties caused by lime and lignite can affect on native AMF colonization in the phytostabilization process involving $L$. perenne.

\section{Conclusion}

The major findings of presented research are as follows:

- The application of lime and lignite decrease the investigated heavy metals $(\mathrm{Pb}, \mathrm{Cd}$ and $\mathrm{Zn})$ bioavailable fraction $\left(\mathrm{CaCl}_{2}\right.$ extractable) in the contaminated soil.

- Used amendments increased the shoot dry biomass, as well as decreased heavy metals concentration in the roots and shoots of L. perenne.

- Structures characteristic for AMF was observed in $L$. perenne roots irrespective of the amendments dose

- The amended treatments increased the arbuscules occurrence (A\%) in L. perenne roots, while the dose of $0.5 \%$ lime and 5\% lignite resulted in a better relative mycorrhizal intensity colonization value (M\%) than $0.25 \%$ lime and 5\% lignite dose.

The novelty of conducted experiment is related to effect of applied amendments on the native AMF L. perenne root colonization. Despite this fact, further analyses would be required, based on spore morphology, to explain the different responses of both AMF and microorganisms communities to the different treatments. Moreover, effect of this approach should be further validated in the field scale application.

In general, phytostabilization of heavily contaminated soil could serve as solution, where the other methods of remediation can not be applied, from technical and economical point of view. Additional advantage of such approach is related to the improvement in soil biodiversity, particularly 
plant - AMF symbiosis. The results of the experiment were implemented to stabilize heavy metals during remediation of a spoil heap in Ruda Śląska, Poland, aimed at an environmental restoration of the site in order to enable its use as public space for recreational purposes. Phytostabilization, in this case, was an important part of the investment which mitigated the risk of further contaminants spread.

Acknowledgements The investigations presented in the article have been performed in the framework of the project LUMAT - Implementation of Sustainable Land Use in Integrated Environmental Management of Functional Urban Areas, financed by the INTERREG Programme for Central Europe (CE89 LUMAT). The phytostabilization technology has been applied within the project investment on the area of $12266 \mathrm{~m}^{2}$.

Authors contribution The authors contributions are as follows: ASB performed the experimental work, analyzed the data and wrote the manuscript (60\%), JK planned and designed the research and wrote the manuscript (10\%), SR performed the statistical analysis and wrote the manuscript (10\%), ASS and IRK contributed to the manuscript including language corrections (5\%), MP planned and designed the research and contributed to the manuscript (10\%).

\section{Declarations}

Conflict of interest The authors declare no conflicts of interest.

Ethical approval This article does not contain any studies with human participants performed by any of the authors.

Open Access This article is licensed under a Creative Commons Attribution 4.0 International License, which permits use, sharing, adaptation, distribution and reproduction in any medium or format, as long as you give appropriate credit to the original author(s) and the source, provide a link to the Creative Commons licence, and indicate if changes were made. The images or other third party material in this article are included in the article's Creative Commons licence, unless indicated otherwise in a credit line to the material. If material is not included in the article's Creative Commons licence and your intended use is not permitted by statutory regulation or exceeds the permitted use, you will need to obtain permission directly from the copyright holder. To view a copy of this licence, visit http://creativecommons.org/licenses/by/4.0/.

\section{References}

Amoah-Antwi C, Kwiatkowska-Malina J, Szara E, Thornton S, Fenton O, Malina G (2020) Efficacy of woodchip biochar and brown coal waste as stable sorbents for abatement of bioavailable cadmium, lead and zinc in soil. Water Air Soil Pollut 231(10):1-17

Bąba W, Błońska A, Kompała-Bąba A, Małkowski Ł, Ziemer B, Sierka E, Nowak T, Woźniak G, Besenyei L (2016) Arbuscular mycorrhizal fungi (AMF) root colonization dynamics of Molinia caerulea (L.) Moench. in grasslands and post-industrial sites. Ecol Eng 95:817-827

Barbosa B, Fernando AL (2018) Aided phytostabilization of mine waste. In Prasad SK, de Favas MNV, Maiti PJC (Eds) Bio-geotechnologies for mine site rehabilitation. Amsterdam Elsevier, pp $147-157$
Begum N, Qin C, Ahanger MA, Raza S, Khan MI, Ashraf M, Ahmed N, Zhang L (2019) Role of arbuscular mycorrhizal fungi in plant growth regulation: implications in abiotic stress tolerance. Fron Plant Sci 10:1068

Berthelot C, Blaudez D, Beguiristain T, Chalot M, Leyval C (2018) Co-inoculation of Lolium perenne with Funneliformis mosseae and the dark septate endophyte Cadophora sp. in a trace elementpolluted soil. Mycorrhiza 28(3):301-314

Bidar G, Waterlot C, Verdin A, Proix N, Courcot D, Détriché S, Douay F (2016) Sustainability of an in situ aided phytostabilisation on highly contaminated soils using fly ashes: effects on the vertical distribution of physicochemical parameters and trace elements. $\mathbf{J}$ Environ Manag 171:204-216

Briceño J, Márquez M, Sánchez K, Armado A (2018) Lignite as organic amendment in a dross afected soils. Ital J Food Sci 31(5):164-170

Burges A, Epelde L, Benito G, Artetxe U, Becerril JM, Garbisu C (2016) Enhancement of ecosystem services during endophyteassisted aided phytostabilization of metal contaminated mine soil. Sci Total Environ 562:480-492

Cabral L, Soares CRFS, Giachini AJ, Siqueira JO (2015) Arbuscular mycorrhizal fungi in phytoremediation of contaminated areas by trace elements: mechanisms and major benefits of their applications. World J Microbiol Biotechnol 31(11):1655-1664

Cao X, Hu P, Tan C, Wu L, Peng B, Christie P, Luo Y (2018) Effects of a natural sepiolite bearing material and lime on the immobilization and persistence of cadmium in a contaminated acid agricultural soil. Environ Sci Pollut Res 25(22):22075-22084

Carballar-Hernández S, Hernández-Cuevas LV, Montaño NM, Larsen J, Ferrera-Cerrato R, Taboada-Gaytán OR, Alarcón A (2017) Native communities of arbuscular mycorrhizal fungi associated with Capsicum annuum L. respond to soil properties and agronomic management under field conditions. Agric Ecosyst Environ 245:43-51

Cely MVT, de Oliveira AG, de Freitas VF, de Luca MB, Barazetti AR, dos Santos IMO, Gionco B, Garcia GV, Prete CEC, Andrade G (2016) Inoculant of arbuscular mycorrhizal fungi (Rhizophagus clarus) increase yield of soybean and cotton under field conditions. Front Microbiol 7:720

Chang Q, Diao FW, Wang QF, Pan L, Dang ZH, Guo W (2018) Effects of arbuscular mycorrhizal symbiosis on growth, nutrient and metal uptake by maize seedlings (Zea mays L.) grown in soils spiked with Lanthanum and Cadmium. Environ Pollut 241:607-615

Chen YP, Chen D, Liu Q (2017) Exposure to a magnetic field or laser radiation ameliorates effects of $\mathrm{Pb}$ and $\mathrm{Cd}$ on physiology and growth of young wheat seedlings. J Photochem Photobiol B: Biol 169:171-177

Cui H, Fan Y, Xu L, Zhou J, Zhou D, Mao J, Zhu Z (2016) Sustainability of in situ remediation of $\mathrm{Cu}$-and $\mathrm{Cd}$-contaminated soils with one-time application of amendments in Guixi China. J Soils Sediments 16(5):1498-1508

Das M, Jakkula VS, Adholeya A (2017) Role of mycorrhiza in phytoremediation processes: a review. In: Varma A, Prasad R, Tuteja $\mathrm{N}$ (eds) Mycorrhiza-Nutrient uptake, biocontrol, ecorestoration. Springer, Cham, pp 271-286

Della Mónica IF, Saparrat MC, Godeas AM, Scervino JM (2015) The co-existence between DSE and AMF symbionts affects plant $\mathrm{P}$ pools through $\mathrm{P}$ mineralization and solubilization processes. Fungal Ecol 17:10-17

Emamverdian A, Ding Y, Mokhberdoran F, Xie Y (2015) Heavy metal stress and some mechanisms of plant defense response. Sci World J 2015:1-18

España H, Bas F, Zornoza R, Masaguer A, Gandarillas M, Arellano E, Ginocchio R (2019) Effectiveness of pig sludge as organic amendment of different textural class mine tailings with different periods of amendment-contact time. J Environ Manag 230:311-318 
Fiorentino N, Mori M, Cenvinzo V, Duri LG, Gioia L, Visconti D, Fagnano M (2018) Assisted phytoremediation for restoring soil fertility in contaminated and degraded land. Ital J Agron 13(s1):34-44

Fresno T, Moreno-Jiménez E, Zornoza P, Peñalosa JM (2018) Aided phytostabilisation of As-and $\mathrm{Cu}$-contaminated soils using white lupin and combined iron and organic amendments. J Environ Manag 205:142-150

Gomes EA, Oliveira CA, Lana UG, Noda RW, Marriel IE, De Souza FA (2015) Arbuscular mycorrhizal fungal communities in the roots of maize lines contrasting for $\mathrm{Al}$ tolerance grown in limed and non-limed Brazilian Oxisoil. J Microbiol Biotechnol 25(7):978-987

Gonneau C, Miller K, Mohanty SK, Xu R, Hwang WT, Willenbring JK, Casper BB (2017) Framework for assessment and phytoremediation of asbestos-contaminated sites. Environ Sci Pollut Res 24(33):25912-25922

Goulding KWT (2016) Soil acidification and the importance of liming agricultural soils with particular reference to the United Kingdom. Soil Use Manag 32(3):390-399

Gu H, Zhou Z, Gao Y, Yuan X, Ai Y, Zhang J, Zuo W, Taylor AA, Nan S, Li F (2017) The influences of arbuscular mycorrhizal fungus on phytostabilization of lead/zinc tailings using four plant species. Int J Phytoremediation 19(8):739-745

Gucwa-Przepióra E, Małkowski E, Sas-Nowosielska A, Kucharski R, Krzyżak J, Kita A, Römkens PF (2007) Effect of chemophytostabilization practices on arbuscular mycorrhiza colonization of Deschampsia cespitosa ecotype Waryński at different soil depths. Environ Pollut 150(3):338-346

Gunathilakae N, Yapa N, Hettiarachchi R (2018) Effect of arbuscular mycorrhizal fungi on the cadmium phytoremediation potential of Eichhornia crassipes (Mart.) Solms. Groundw Sustain Develop 7:477-482

Hanus-Fajerska EJ, Koźmińska A (2016) The possibilities of water purification using phytofiltration methods: a review of recent progress. BioTechnologia J Biotechnol Comput Biol Bionanotechnol 97(4):315-322

Hartley W, Lepp NW (2008) Effect of in situ soil amendments on arsenic uptake in successive harvests of ryegrass (Lolium perenne cv Elka) grown in amended As-polluted soils. Environ Pollut 156(3):1030-1040

Hazard C, Gosling P, Van Der Gast CJ, Mitchell DT, Doohan FM, Bending GD (2013) The role of local environment and geographical distance in determining community composition of arbuscular mycorrhizal fungi at the landscape scale. ISME J 7(3):498-508

Hazard C, Boots B, Keith AM, Mitchell DT, Schmidt O, Doohan FM, Bending GD (2014) Temporal variation outweighs effects of biosolids applications in shaping arbuscular mycorrhizal fungi communities on plants grown in pasture and arable soils. Appl Soil Ecol 82:52-60

Hechelski M, Louvel B, Dufrénoy P, Ghinet A, Waterlot C (2019) Effects of calcium phosphates on the ( $\mathrm{Im}$ ) mobilization of metals and nutrients, on the biological activity and on the plant health from multi-contaminated urban soils. Water Air Soil Pollut 230(8):206

Heyburn J, McKenzie P, Crawley MJ, Fornara DA (2017) Long-term belowground effects of grassland management: the key role of liming. Ecol Appl 27(7):2001-2012

Hossain MA, Piyatida P, da Silva JAT, Fujita M (2012) Molecular mechanism of heavy metal toxicity and tolerance in plants: central role of glutathione in detoxification of reactive oxygen species and methylglyoxal and in heavy metal chelation. J Bot 2012, Article ID 872875

ISO 11466, 1995. Soil Quality d Extraction of Trace Elements Soluble in Aqua Regia
Jiang Y, Shi L, Guang AL, Mu Z, Zhan H, Wu Y (2018) Contamination levels and human health risk assessment of toxic heavy metals in street dust in an industrial city in Northwest China. Environ Geochem Health 40(5):2007-2020

Jin Y, Liu W, Li XL, Shen SG, Liang SX, Liu C, Shan L (2016) Nanohydroxyapatite immobilized lead and enhanced plant growth of ryegrass in a contaminated soil. Ecol Eng 95:25-29

Joner EJ, Briones R, Leyval C (2000) Metal-binding capacity of arbuscular mycorrhizal mycelium. Plant Soil 226(2):227-234

Junior PP, Moreira BC, da Silva MDCS, Veloso TGR, Stürmer SL, Fernandes RBA, Kasuya MCM (2019) Agroecological cofee management increases arbuscular mycorrhizal fungi diversity. PLoS One 14:1-19

Jutsz AM, Gnida A (2015) Mechanisms of stress avoidance and tolerance by plants used in phytoremediation of heavy metals. Arch Environ Prot 41(4):104-114

Kacprzak M, Grobelak A, Grosser A, Prasad MNV (2014) Efficacy of biosolids in assisted phytostabilization of metalliferous acidic sandy soils with five grass species. Int $\mathrm{J}$ Phytoremediation 16(6):593-608

Khanna K, Kohli SK, Sharma A, Ohri P, Bhardwaj R, Al-Huqail AA, Siddiqui HM, Ahmad P (2020) Histochemical and physicochemical studies reveal improved defense in tomato under Cd stress with rhizobacterial supplementation. Plant Soil 446(1):393-411

Laghlimi M, Baghdad B, El Hadi H, Bouabdli A (2015) Phytoremediation mechanisms of heavy metal contaminated soils: a review. Open J Ecol 5(08):375

Lahori AH, Zhang Z, Guo Z, Mahar A, Li R, Awasthi MK, Sial TA, Kumbhar F, Wang P, Shen F, Zhao J, Huang H (2017) Potential use of lime combined with additives on (im)mobilization and phytoavailability of heavy metals from $\mathrm{Pb} / \mathrm{Zn}$ smelter contaminated soils. Ecotoxicol Environ Saf 145:313-323

Latef AA, Hashem A, Rasool S, Abd-Allah EF, Alqarawi AA, Egamberdieva D, Jan S, Anjum NA, Ahmad P (2016) Arbuscular mycorrhizal symbiosis and abiotic stress in plants: a review. J Plant Biol 59(5):407-426

Lee SH, Ji W, Lee WS, Koo N, Koh IH, Kim MS, Park JS (2014) Influence of amendments and aided phytostabilization on metal availability and mobility in $\mathrm{Pb} / \mathrm{Zn}$ mine tailings. J Environ Manag 139:15-21

Li X, Meng D, Li J, Yin H, Liu H, Liu X, Yan M (2017) Response of soil microbial communities and microbial interactions to longterm heavy metal contamination. Environ Pollut 231:908-917

Lin J, Wang Y, Sun S, Mu C, Yan X (2017) Effects of arbuscular mycorrhizal fungi on the growth, photosynthesis and photosynthetic pigments of Leymus chinensis seedlings under salt-alkali stress and nitrogen deposition. Sci Total Environ 576:234-241

Liu H, Yuan M, Tan S, Yang X, Lan Z, Jiang Q, Ye Z, Jing Y (2015) Enhancement of arbuscular mycorrhizal fungus (Glomus versiforme) on the growth and $\mathrm{Cd}$ uptake by $\mathrm{Cd}$-hyperaccumulator Solanum nigrum. Appl Soil Ecol 89:44-49

Liu H, Xu F, Xie Y, Wang C, Zhang A, Li L, Xu H (2018) Effect of modified coconut shell biochar on availability of heavy metals and biochemical characteristics of soil in multiple heavy metals contaminated soil. Sci Total Environ 645:702-709

Luo Y, Wu Y, Shu J, Wu Z (2019) Effect of particulate organic matter fractions on the distribution of heavy metals with aided phytostabilization at a zinc smelting waste slag site. Environ Pollut 253:330-341

Malcová R, Vosátka M, Gryndler M (2003) Effects of inoculation with Glomus intraradices on lead uptake by Zea mays L. and Agrostis capillaris L. Appl Soil Ecol 23(1):55-67

Malik RN, Husain SZ, Nazir I (2010) Heavy metal contamination and accumulation in soil and wild plant species from industrial area of Islamabad Pakistan. Pak J Bot 42(1):291-301 
Martínez-Martínez S, Zornoza R, Gabarrón M, Gómez-Garrido M, Rosales RM, Muñoz MA, Acosta JA (2019) Is aided phytostabilization a suitable technique for the remediation of tailings? Eur J Soil Sci 70(4):862-875

Miransari M (2010) Contribution of arbuscular mycorrhizal symbiosis to plant growth under different types of soil stress. Plant Biol 12(4):563-569

Moreno-Jiménez E, Sepúlveda R, Esteban E, Beesley L (2017) Efficiency of organic and mineral based amendments to reduce metal [loid] mobility and uptake (Lolium perenne) from a pyrite-waste contaminated soil. J Geochem Explor 174:46-52

Nava G, Santos KLD, Costa MD, Ciotta MN (2016) Growth, mineral composition, fruit yield, and mycorrhizal colonization of feijoa in response to lime and phosphorus application. Pesqui Agropecu Bras 51(8):942-949

Norini MP, Thouin H, Miard F, Battaglia-Brunet F, Gautret P, Guégan R, Motelica-Heino M (2019) Mobility of Pb, Zn, Ba, As and Cd toward soil pore water and plants (willow and ryegrass) from a mine soil amended with biochar. J Environ Manag 232:117-130

Nowak K, Szada-Borzyszkowska A, Krzyzak J, Rusinowski S, Soja M, Pogrzeba M (2019) Comparison of root colonization by arbuscular mycorrhizal fungi in energy crop species cultivated on arable land contaminated with heavy metals. In: IOP Conference Series: Earth and Environmental Science, vol 214, no 1, p 012030

Oehl F, Sieverding E, Ineichen K, Mäder P, Boller T, Wiemken A (2003) Impact of land use intensity on the species diversity of arbuscular mycorrhizal fungi in agroecosystems of Central Europe. Appl Environ Microbiol 69(5):2816-2824

Öpik M, Zobel M, Cantero J, Davison J, Facelli J, Hiiesalu I, Jairus T, Kalwij J, Koorem K, Leal M, Liira J, Metsis M, Neshataeva V, Paal J, Phosri C, Põlme S, Reier Ü, Saks Ü, Schimann H, Thiery O, Vasar M, Moora M (2013) Global sampling of plant roots expands the described molecular diversity of arbuscular mycorrhizal fungi. Mycorrhiza 23(5):411-430

Orłowska E, Orłowski D, Mesjasz-Przybyłowicz J, Turnau K (2010) Role of mycorrhizal colonization in plant establishment on an alkaline gold mine tailing. Int J Phytoremediation 13(2):185-205

Parihar M, Rakshit A, Singh HB, Rana K (2019) Diversity of arbuscular mycorrhizal fungi in alkaline soils of hot sub humid ecoregion of Middle Gangetic Plains of India. Acta Agr Scand B S P 69(5):386-397

Parmar S, Singh V (2015) Phytoremediation approaches for heavy metal pollution: a review. J Plant Sci Res 2(2):135-142

Phillips JM, Hayman DS (1970) Improved procedures for clearing roots and staining parasitic and vesicular-arbuscular mycorrhizal fungi for rapid assessment of infection. Trans Br Mycol Soc 55:158-161

Pogrzeba M, Rusinowski S, Sitko K, Krzyżak J, Skalska A, Małkowski E, Ciszek D, Werle S, McCalmont JP, Mos M, Kalaji HM (2017) Relationships between soil parameters and physiological status of Miscanthus x giganteus cultivated on soil contaminated with trace elements under NPK fertilisation vs. microbial inoculation. Environ Pollut 225:163-174

Pogrzeba M, Rusinowski S, Krzyżak J, Szada-Borzyszkowska A, McCalmont JP, Zieleźnik-Rusinowska P, Sas-Nowosielska A (2019) Dactylis glomerata L. cultivation on mercury contaminated soil and its physiological response to granular sulphur aided phytostabilization. Environ Pollut 255:11327

Radziemska M (2017) Aided phytostabilization of copper contaminated soils with L. perenne and mineral sorbents as soil amendments. Civ Environ Eng Rep 26(3):79-89

Radziemska M (2018) Study of applying naturally occurring mineral sorbents of Poland (dolomite halloysite, chalcedonite) for aided phytostabilization of soil polluted with heavy metals. CATENA 163:123-129
Radziemska M, Gusiatin ZM, Bilgin A (2017) Potential of using immobilizing agents in aided phytostabilization on simulated contamination of soil with lead. Ecol Eng 102:490-500

Radziemska M, Bilgin A, Vaverková MD (2018) Application of mineral based amendments for enhancing phytostabilization in Lolium perenne L. cultivation. Clean: Soil, Air, Water 46(1):1600679

Rajtor M, Piotrowska-Seget Z (2016) Prospects for arbuscular mycorrhizal fungi (AMF) to assist in phytoremediation of soil hydrocarbon contaminants. Chemosphere 162:105-116

Regulation of the Minister of Environment (Official Journal of Laws of the Republic of Poland of 2016 item 1395)

Rusinowski S, Szada-Borzyszkowska A, Zieleźnik-Rusinowska P, Małkowski E, Krzyżak J, Woźniak G, Sitko K, Szopiński M, McCalmont JP, Kalaji HM, Pogrzeba M (2019) How autochthonous microorganisms influence physiological status of Zea mays L. cultivated on heavy metal contaminated soils? Env Sci Pollut Res 26(5):4746-4763

Schierup HH, Larsen VJ (1981) Macrophyte cycling of zinc, copper, lead and cadmium in the littoral zone of a polluted and a non-polluted lake. Availability, uptake and translocation of heav metals in Phragmites australis (Cav.). Trin Aquat Bot 11:197-210

Schneider J, Bundschuh J, do Nascimento CWA (2016) Arbuscular mycorrhizal fungi-assisted phytoremediation of a lead-contaminated site. Sci Total Environ 572:86-97

Seguel A, Cumming J, Cornejo P, Borie F (2016) Aluminum tolerance of wheat cultivars and relation to arbuscular mycorrhizal colonization in a non-limed and limed Andisol. Appl Soil Ecol 108:228-237

Shackira AM, Puthur JT (2019) Phytostabilization of heavy metals: Understanding of principles and practices. In: Srivastava S, Srivastava AK, Suprasanna P (eds) Plant-Metal Interactions. Springer, Cham, pp 263-282

Shahid M, Khalid S, Abbas G, Shahid N, Nadeem M, Sabir M, Aslam M, Dumat C (2015) Heavy metal stress and crop productivity. In: Hakeem KR (ed) Crop production and global environmental issues. Springer International Publishing, Switzerland, pp 1-25

Simmler M, Ciadamidaro L, Schulin R, Madejón P, Reiser R, Clucas L, Weber P, Robinson B (2013) Lignite reduces the solubility and plant uptake of cadmium in pasturelands. Environ Sci Technol 47:4497-5450

Singh J, Kalamdhad AS (2013) Bioavailability and leachability of heavy metals during water hyacinth composting. Chem Speciat Bioavailab 25(1): 1-14

Singh J, Kalamdhad AS (2016) Effect of lime on speciation of heavy metals during composting of water hyacinth. Front Environ Sci Eng 10(1):93-102

Smith SE, Read DJ (2010) Mycorrhizal symbiosis. Academic press, Cambridge UK

Trouvelot A, Kough JL, Gianinazzi-Pearson V (1986) Mesure du taux de mycorhization VA d'un systeme radiculaire. Recherche de methods d'estimation ayant une signification fonctionnelle. In: Gianinazzi-Pearson V, Gianinazzi S (eds) Physiological and genetical aspects of mycorrhizae. INRA, Paris, pp 217-221 ((in French))

Wani W, Masoodi KZ, Zaid A, Wani SH, Shah F, Meena VS, Mosa KA (2018) Engineering plants for heavy metal stress tolerance. Rend Lincei Sci Fis Nat 29(3):709-723

Wu S, Zhang X, Chen B, Wu Z, Li T, Hu Y, Sun Y, Wang Y (2016) Chromium immobilization by extraradical mycelium of arbuscular mycorrhiza contributes to plant chromium tolerance. Environ Exper Bot 122:10-18

Xiao C, Guo S, Wang Q, Chi R (2019) Enhanced reduction of lead bioavailability in phosphate mining wasteland soil by a phosphatesolubilizing strain of Pseudomonas sp., LA, coupled with ryegrass 
(Lolium perenne L.) and sonchus (Sonchus oleraceus L.). Environ Pollut 274:116572

Xin JP, Zhang Y, Tian RN (2018) Tolerance mechanism of Triarrhena sacchariflora (maxim.) Nakai. Seedlings to lead and cadmium: translocation, subcellular distribution, chemical forms and variations in leaf ultrastructure. Ecotox Environ Safety 165:611-621

Yang Y, Liang Y, Ghosh A, Song Y, Chen H, Tang M (2015a) Assessment of arbuscular mycorrhizal fungi status and heavy metal accumulation characteristics of tree species in a lead-zinc mine area: potential applications for phytoremediation. Environ Sci Pollut Res 22(17):13179-13193

Yang Y, Song Y, Scheller HV, Ghosh A, Ban Y, Chen H, Tang M (2015b) Community structure of arbuscular mycorrhizal fungi associated with Robinia pseudoacacia in uncontaminated and heavy metal contaminated soils. Soil Biol Biochem 86:146-158

Yang Y, Liang Y, Han X, Chiu TY, Ghosh A, Chen H, Tang M (2016) The roles of arbuscular mycorrhizal fungi (AMF) in phytoremediation and tree-herb interactions in $\mathrm{Pb}$ contaminated soil. Sci Rep 6:20469
Zhan F, He Y, Yue X, Qin L, Xia Y (2016) Effect of mycorrhizal inoculation on plant growth, nutrients and heavy metals uptake by Leucaena leucocephala. Fresen Environ Bull 25:1760-1767

Zhang Y, Li T, Zhao ZW (2013) Colonization characteristics and composition of dark septate endophytes (DSE) in a lead and zinc slag heap in Southwest China. Soil Sediment Contam Inter J 22(5):532-545

Zhang H, Xu N, Li X, Long J, Sui X, Wu Y, Li J, Wang J, Zhong H, Sun GY (2018) Arbuscular mycorrhizal fungi (Glomus mosseae) improves growth, photosynthesis and protects photosystem II in leaves of Lolium perenne L. in cadmium contaminated soil. Front Plant Sci 9:1156

Zhuang P, Yang QW, Wang HB, Shu WS (2007) Phytoextraction of heavy metals by eight plant species in the field. Water Air Soil Pollut 184(1-4):235-242 